\title{
Making Globalization Inclusive: Job Creation and Wage Inequality in Developing Economies
}

\section{Karim El Aynaoui ${ }^{1,2} \cdot$ Aomar Ibourk ${ }^{1,3}$. Prakash Loungani ${ }^{1,4}$}

Published online: 10 September 2019

(C) Springer Science+Business Media, LLC, part of Springer Nature 2019

Thirty years ago, the fall of the Berlin Wall and the subsequent fall of the Soviet Union brought about the demise of large-scale central planning as a way of organizing the production and distribution of an economy's resources. Since then, developing countries have moved, at different times and at varying speeds, toward market-based systems and integration with the world economy. This transition has brought about a vast increase in living standards and historic reductions in poverty. Not surprisingly, opinion polls indicate strong support for globalization in developing economies, at a time when there is a backlash against it in advanced economies.

To maintain support for pro-market policies and globalization in developing economies, it is important to pay attention to issues of job creation and inclusion, viz., the extent to which the gains from pro-market policies and globalization are being broadly shared across segments of society. Ignoring inclusion would risk making the mistake made in advanced economies - where developments such as a stagnant median income for three decades in some countries were ignored by mainstream politicians and economists - and provoking a similar backlash.

Some of the papers in this special issue were initially presented at a September 2016 conference on Global Labor Markets organized by the IMF, Policy Center for the New South and Brunel University, while others were commissioned through a call for papers. Funding for this initiative was provided in part through the IMFDFID program on Macroeconomic Research in Low Income Countries. Views expressed in this introduction and in the papers are those of the authors and should not be ascribed to the IMF or DFID.

Prakash Loungani

ploungani@imf.org

Karim El Aynaoui

k.elaynaoui@ocpgroup.ma

Aomar Ibourk

aomaribourk@gmail.com

1 Policy Center for the New South, Rabat, Morocco

2 Mohamed VI Polytechnic University, Ben Guerir, Morocco

3 Cadi Ayyad University, Marrakesh, Morocco

4 IMF, Washington, DC, USA 
This special issue is devoted to two important questions that policymakers in developing countries need to ask in their quest for a more inclusive globalization:

- To what extent is growth translating into job creation?

- What is happening to wage inequalities as average incomes are growing?

Growth without adequate job creation is a recipe for social unrest. Growth accompanied by excessive inequality — even if absolute incomes are rising for all — could be perceived as unfair and may not be sustainable.

Three papers in the special issue take a detailed look at the short-run and long-run link between growth and jobs in developing countries.

- Ball, Furceri, Leigh and Loungani estimate Okun's Law for 71 countries (29 advanced economies, 42 emerging and developing economies-EMDEs). As might be expected, the Okun coefficient - the short-run responsiveness of unemployment to output - is smaller in absolute value in EMDEs than in advanced economies: the average coefficient is -0.2 in the latter compared to -0.4 in the former. However, an important finding of the paper is that there is considerable heterogeneity among EMDEs in the Okun coefficient and the fit of Okun's Law for developing countries. There are a number of EMDEs - among them Colombia, Egypt, Poland and Russia-where short-run cyclical fluctuations play an important role in unemployment developments. This finding raises the possibility that as EMDEs become richer, the features of their economies that currently lead to a low Okun coefficient, such as informality and importance of the agricultural sector, will change and make unemployment driven more by cyclical than structural factors.

- An, Ghazi, Ibourk and Gonzalez-Prieto study the link, both in the medium-to-long run and the short-run, between job creation and real GDP growth in 25 low- and lower middle-income countries. A novel feature of the paper is that it looks at the impact of trend breaks in output growth (which are common in these countries) on labor market outcomes. Unfortunately, the findings are not encouraging: out of 17 cases the paper identifies of a trend improvement in GDP growth, only 3 cases are associated with a corresponding trend improvement in employment growth. More analysis is needed to understand this disconcerting disconnect and the actions and policies needed to ensure that growth translates into job creation. As expected, the short-run relationship between growth and employment in these economies is weaker than that in the EMDEs studied in the previous paper.

- Madhou and Sewak estimate structural unemployment and potential output for four African economies-Ghana, Kenya, Mauritius and South Africa-which are essentially inflation-targeters. Hence, the estimation of output and unemployment gaps is important for the conduct of short-run monetary policy in these economies, just as in the advanced economies. Encouragingly, the multivariate filtering techniques used in the case of advanced economies also deliver reasonable results for these four economies. Output and unemployment gaps seem informative about the build-up of inflationary pressures, suggesting that these estimates can be useful to central bankers in these economies. The authors also study the determinants of structural unemployment in these economies and find that increased government spending on education, a competitive exchange rate, and boosting the level of 
financial development (measured as the market capitalization of listed companies) can play a role in lowering structural unemployment.

These three papers greatly expand the stock of knowledge about labor markets in developing economies and particularly for African economies, which is an understudied area even though it is a populous part of the world and one which will experience strong labor force growth in coming decades.

The other four papers look at the impact of integration on inequality in developing economies. Of course, inequality in incomes is an essential feature of market economies. But excessive levels of inequality or a persistent failure of certain segments of an economy to catch up with the rest (e.g. incomes in some regions or for some class of workers such as low-skilled workers) can be an indication of monopoly power, appropriation by vested interests, or lack of opportunity for some people in society. If not addressed, excessive levels of inequality, particularly between high-skilled and lowunskilled workers, can be a source of social and political conflict, in turn jeopardizing average growth. Against this backdrop, the papers in this special issue make theoretical and empirical contributions to understanding the evolution of inequality in developing economies.

- Hellier augments the traditional 2-country 'North-South' Heckscher-OhlinSamuelson (HOS) model with some realistic features to generate rich patterns of inequality dynamics. Specifically, he assumes that that are several Northern (advanced) and Southern (developing) countries with vastly different skill endowments and technology and that the size of the South increases over time. With these assumptions, the model generates growing inequality in the North as the purchasing power of unskilled workers decreases. Unlike the traditional HOS model, this extended model's predictions better fit observed facts about inequality.

- Marjit and Kar also depart from the standard HOS model to consider the crucial role of land as an input in both agriculture and industry. They show that the wage gap between high-skilled and low-skilled workers in a developing country that is opening up to foreign capital can depend in part on the ease with which land can be converted from agricultural to industrial uses. Transferring land from agriculture to industry is a known problem in many low and middle-income countries around the world. If land is scarce in the industrial sector-which uses unskilled labor - capital flows can increase the return to land and lead to a decline in the relative wage of unskilled to skilled labor. This model may provide an theoretical channel for the observed increase in inequality after capital account liberalization.

- $\quad \mathrm{Li}$, Cai and Chakraborty analyze how the wage gap between skilled and unskilled workers in Chinese cities changes when they carry out policies that make them more integrated domestically and internationally. They measure these policies using a novel measure of market access. For cities starting out from a low level of market access, policies that further increase market access lead to an increase in the wage gap as these cities try to attract skilled labor from other areas. In contrast, in cities that already have high market access and a pool of skilled labor, further integration can actually dampen the wage premium for skilled workers.

- Martinez-Zarzozo studies the impact of Free Trade Agreements (FTAs) on labor market conditions in ratifying countries using a panel of nearly 100 countries from 
1995 to 2008. There has been much concern in recent years about the impact on international trade on wage inequality. Much of the expansion of trade has taken place through FTAs, many of which contain provisions to help labor market outcomes for low-skilled workers and those at risk of losing jobs from trade. The author finds the inclusion of such provisions does contribute to improved labour conditions in participating countries through increases in the ratio of minimum wage to median wage, unemployment benefits, coverage ratios and severance payments. Hence, contrary to perceptions, FTAs may have helped prevent a 'global race to the bottom.'

Developing countries account for large shares of the world's population and its labor force. These shares are projected to increase. This makes it important to lavish as much attention to labor markets in these countries as is done for labor markets in advanced economies. This special issue is a step in this direction.

Publisher's Note Springer Nature remains neutral with regard to jurisdictional claims in published maps and institutional affiliations. 